\title{
Biodegradation of the Ametryne in Soil with Addition of Biofertilizer
}

\author{
Ana Paula Justiniano Régo (Corresponding author) \\ Department of Biochemistry and Microbiology, State University of São Paulo
}

Av. 24 A, 1515, Brazil

Tel: 55-19-3526-4192Ｅ-mail: anapjustiniano@gmail.com

Cassiana Maria Reganhan Coneglian

Faculty of Technology, State University of Campinas

Rua Paschoal Marmo, $n^{\circ} 1888$, Brazil

Tel: 55-19-2113-3347_E-mail: cassianac@ft.unicamp.br

\begin{abstract}
Ederio Dino Bidoia
Department of Biochemistry and Microbiology, State University of São Paulo
\end{abstract}

Av. 24 A, 1515, Brazil

Tel: 55-19-3526-4192Ｅ-mail: ederio@rc.unesp.br

Received: March 19, 2017 Accepted: March 29, 2017 Published: November 29, 2017

doi:10.5296/jee.v8i2.12209～URL: https://doi.org/10.5296/jee.v8i2.12209

\begin{abstract}
The intensified use of pesticides and chemical fertilizers has resulted in threats to the environment. Thus it is crucial to the implementation of sustainable alternatives in order to mitigate the negative effects. The biofertilizer brings this proposal, as it improves soil fertility and minimize environmental risks. The ametryne herbicide is used for weed control, very soluble in water, bringing risks to terrestrial and aquatic ecosystem. Thus, the objective of this work was to study the degradation of ametryne in soil with the addition of liquid biofertilizers. After application of biofertilizer in soil with ametryne, the microbial activity increased in $39.149 \%$, in $\mathrm{CO}_{2}$ generation. In the assay for quantification of ametryne by HPLC-MS/MS there was reduction of concentration of the molecule in the presence soil
\end{abstract}


sample contaminated with the herbicide. Thus, the biofertilizer was able to assist in soil fertility, increasing metabolic activity, resulting in degradation of the herbicide.

Keywords: Biodegradation, Ametryne, Biofertilizer 


\section{Introduction}

The ametryne belongs to the s-triazines group, is a selective herbicide for weed control in the pre and post emergency period (Duarte et al., 2009). It operates in the inhibition of electron transport in chloroplasts, resulting in phytotoxicological effects even at low concentrations (Sandoval-Carrasco et al., 2013).

This herbicide has low affinity for soil colloids, since it has a low coefficient of sorption and high solubility in water, become a threat to the aquatic ecosystem. The ametryne is soluble in water, a persistent compound and bioaccumulative in the environment, harming terrestrial and aquatic ecosystem. The triazine herbicides are considered one of the main pollutants due to its widespread use and toxicity to the environment. (Farré et al., 2002; Kasozi et al., 2012; Navaratna et al., 2012).

The main environmental pathways of contamination by pesticides (Banderi et al., 2012), are intensive application rates in cultures or accidental spillage (Lima et al., 2009). In order to bring changes in the crop, makes necessary the use of products with maximum yield from natural crops, contributing to pest control, stimulation of plant growth (Pešaković et al., 2013) and mineral enrichment in poor soil phosphorus and potassium (Andrade et al., 2013).

The biofertilizer has properties fermentation of organic compounds, or latent living cells of microorganisms and inorganic nutrients. These products have an intense microbial activity capable of protecting crops against pests and diseases, as well as increase the degree of bioavailability of nutrients to the plants through biological processes (Alfa et al., 2014).

Thus, the biofertilizer helps to increase microbiota in enhancing the photosynthesis process, inhibiting plant pathogens such as plant growth stimulators and detoxification of heavy metals. In studies with strawberry cultivation the biofertilizer, significantly improved fruit length of recommending the replacement of chemical fertilizer for use of biofertilizer, as it improves the financial cost and also the consumption of safe products to health and the environment (Pešaković et al., 2013).

Thus, the biofertilizer rich compound is beneficial microorganisms into the environment and nutrients, which can be used in organic cultures (Wu et al., 2005), through biological processes, resulting in improved soil quality (Jilani et al., 2007).

This study aimed to evaluate the biodegradation of ametryne in soil with addition of biofertilizer by analyzing $\mathrm{CO}_{2}$ generation during the incubation period, but also to evaluate the presence of decreased ametryne by quantifying the molecule by chromatography HPLC-MS/MS.

\section{Materials and Method}

The biofertilizer MICROGEO® (patent \# PI0207342 A2-0) was donated by Microbiol Biotechnology, in the Brazil. This biofertilizer consists of organic compounds, active and dormant cells of bacteria, fungi, algae and yeasts ((D'andrea, 2002). 


\section{Macrothink}

The soil sample was collected in sugarcane growing area with application history, $20 \mathrm{~cm}$ deep, according to standard CETESB (1984). Below (Table 1) described the physicochemical characteristics of the soil.

\subsection{Respirometry Test of Bartha \& Pramer}

The respirometry test was used to evaluate the generation of $\mathrm{CO}_{2}$ in soil ametryne increase and addition of biofertilizer, 31 days incubation. We used the technical standard L6.350 (CETESB, 1990). Table 1 describes the compositions contained in each system respirometers.

Table 1. Respirometric assays composition

\begin{tabular}{cc}
\hline Systems & Composition \\
\hline S1 & 50.0 g soil \\
S2 & 50.0 g soil+ ametryne $(45.00 \mathrm{mg} / \mathrm{kg})+$ biofertilizer $(1 \% \mathrm{~m} / \mathrm{m})$ \\
S3 & 50.0 g soil + ametryne $(45.00 \mathrm{mg} / \mathrm{kg})$ \\
S4 & 50.0 g soil + biofertilizer $(1 \% \mathrm{~m} / \mathrm{m})$ \\
\hline
\end{tabular}

The respirometric method Bartha \& Pramer (1965), was analysed by generation of $\mathrm{CO}_{2}$ from microbial respiration. The assay was described Régo et al. (2014). Readings of $\mathrm{CO}_{2}$ values produced were measuring using standard solution of hydrochloric acid $(\mathrm{HCl})$, solution of potassium hydroxide $(\mathrm{KOH})$, solution barium chloride $\left(\mathrm{BaCl}_{2}\right)$ and phenolphthalein indicator.

\subsection{Statistical Analyzes}

For testing respirometry Bartha \& Pramer was held analyses Friedman statistics, ORIGIN software 8.0 considered $\mathrm{p}<0.05$.

\subsection{Kinetic Models}

To evaluate the kinetics of biodegradation of ametryne was presented models adapted by Schmidt et al. (1985), to describe the maximum amount of accumulated $\mathrm{CO}_{2}$ respirometry test expected in equation (1):

$$
B=B \max /\left(1+\left[\frac{B \max -B o}{B o}\right] e^{-r t}\right)
$$

where $\mathrm{B}$ is the $\mathrm{CO}_{2}$ produced, Bmax is the maximum amount of $\mathrm{CO}_{2}$ produced, Bo is the initial $\mathrm{CO}_{2}$ produced, $\mathrm{r}$ is the specific maximum production rate for each ametryne, $\mathrm{t}$ is the period in which the biodegradation occurs.

\subsection{Quantitative Analyses}

The assay was based on the methods in Analytical Methods for Pesticides Residues in Foodstuffs (2006) and Guidance Document the Pesticide Manual Residue on Analytical 


\section{Macrothink}

methods (2010). The limits of detection were $0.15 \mathrm{mg} / \mathrm{kg}$ and the quantification limit was 0.3 $\mathrm{mg} / \mathrm{kg}$. The equipment used was HPLC-MS/MS API 2000.

\section{Results}

3.1 Assessment of Microbial Activity in Soil Contaminated by Ametryne and with Added Biofertilizer

The Figure 1 shows the amount of $\mathrm{CO}_{2}$ accumulated in soil sample application ametryne addition of biofertilizer and analysed for 31 days and incubated at $28 \mathrm{C}$.

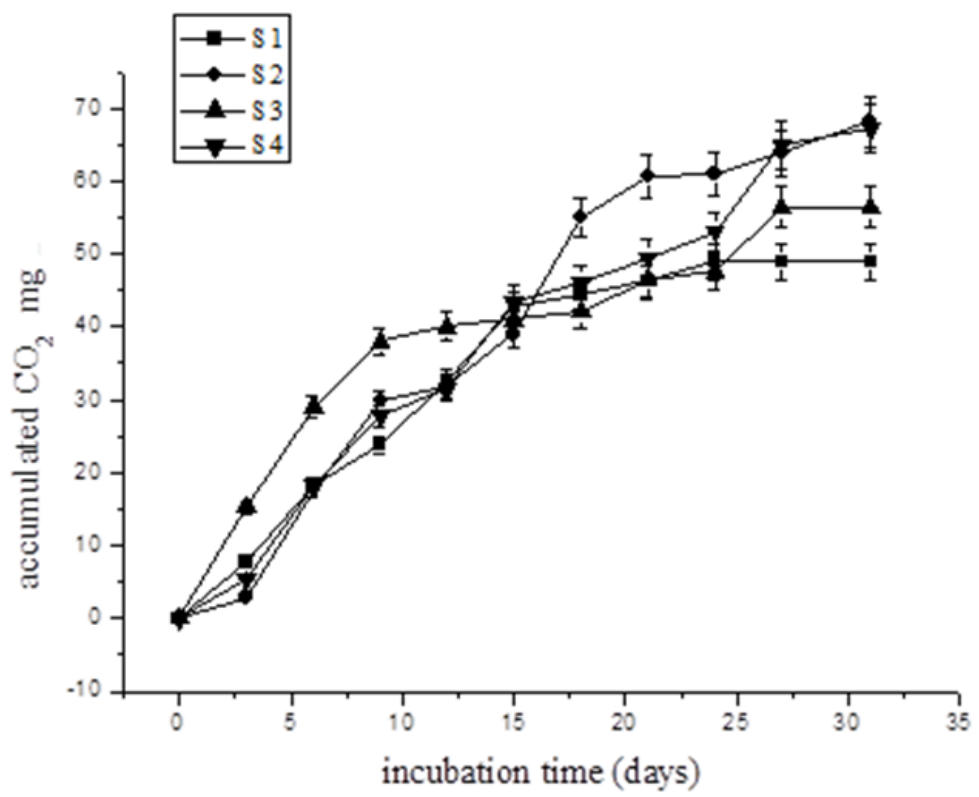

Figure 1. Generation of $\mathrm{CO}_{2}$ accumulated for 31 test days and incubated at $28^{\circ} \mathrm{C}$

The system (S4) with soil and biofertilizer, was the most $\mathrm{CO}_{2}$ accumulated during the test, since it has a carbon source easily assimilated to soil microorganisms.

Contaminating the soil with the herbicide, $\mathrm{CO}_{2}$ accumulation was lower compared to systems with addition of biofertilizer. After 15 days of testing, the system (S2) resulted in increased microbial activity even in the presence of ametryne. This was probably due to addition of biofertilizer. The ametryne probably have toxicity to soil microorganisms, presenting lower microbial activity (S3).

The system (S4) with soil and biofertilizer was obtained more accumulation of $\mathrm{CO}_{2}$, with $43.571 \mathrm{mg}$. This occurred until the middle of the experiment, due to the nutritional character that has biofertilizer. Thus, it constitutes as a way of biostimulation of indigenous microbiota.

From the fifteenth day of incubation, the system (S2) with soil and biofertilizer ametryne generated more than $50.000 \mathrm{mg}$, exceeding the system (S4) with soil and fertilizer. This is due to the consumption of carbon source present in biofertilizers, ending with constant accumulation of $\mathrm{CO}_{2}$. 


\section{Macrothink}

The soil control (S1), which had ametryne application history accumulated less $\mathrm{CO}_{2}$, with $48.981 \mathrm{mg}$ over time relative to other systems.

However, the system with addition of soil and ametryne (S3) produced more $\mathrm{CO}_{2}$ compared to control soil (S1). This soil had already ametryne load over time, making the indigenous microbiota adapted to the presence of the herbicide. By adding more ametryne, was the carbon source in the system increase, stimulating the metabolic activity of soil microorganisms.

By adding biofertilizer to the soil by applying ametryne, it is observed that there was a greater accumulation of $\mathrm{CO}_{2}$ in the soil control and soil with added ametryne. This is due to higher source of bioavailable carbon for microbial metabolism. As the biofertilizer has nutrients and microorganisms in their composition, probably he was able to assist in the metabolism of organic compounds, with ametryne.

After 25 test days, $\mathrm{CO}_{2}$ accumulation stabilizes, because the carbon source has been consumed, leaving the microbial biomass.

The Figure 2 shows the mathematical modelling of the test systems used respirometry Bartha \& Pramer in order to simulate real systems predicting their behaviour over time.
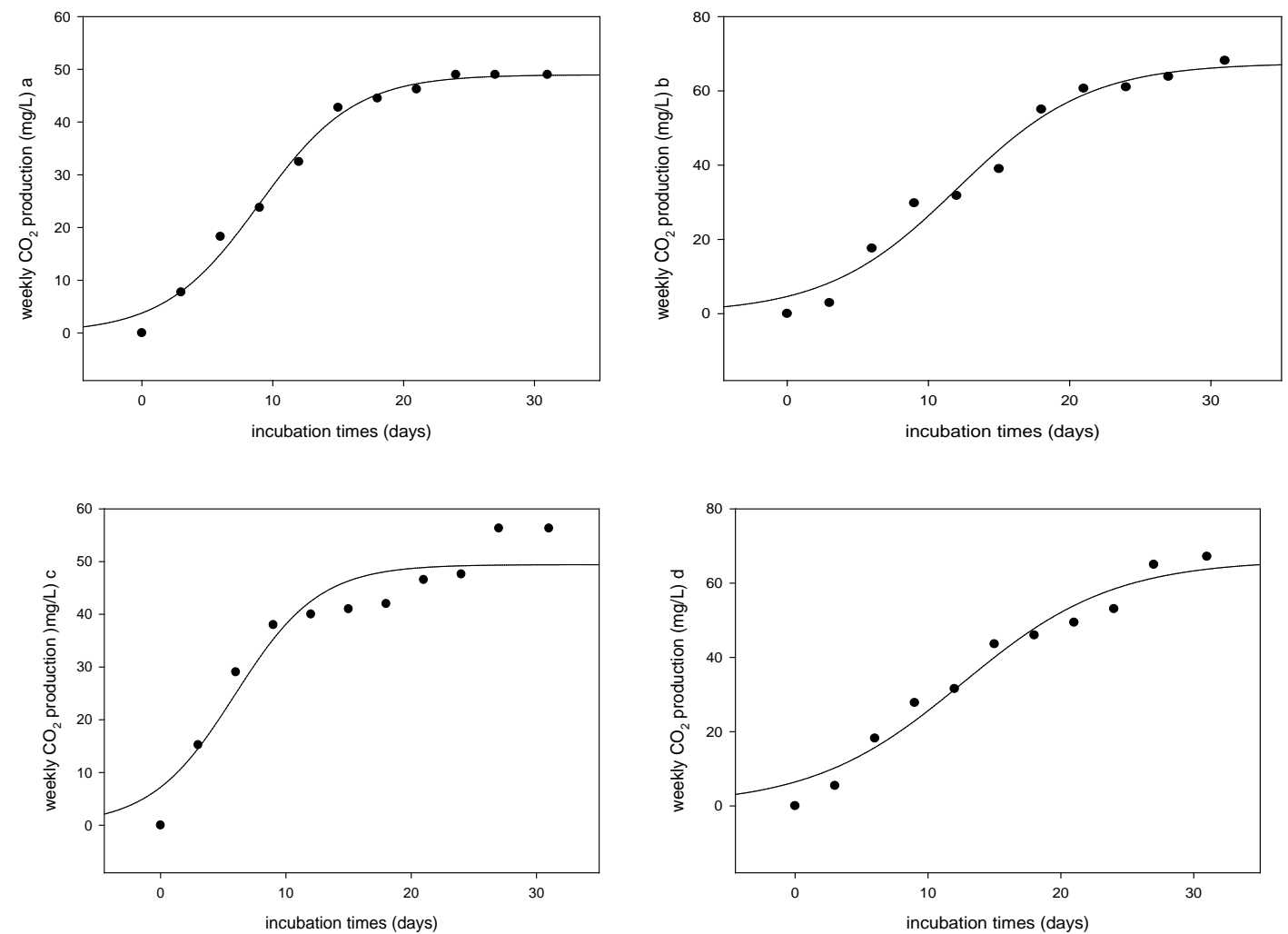

Figure 2. Chart of accumulated $\mathrm{CO}_{2}$ generation, plotted second model of Schmidt et al. (1985) and adapted by Montagnolli et al. (2009), in systems containing control soil (a) soil with ametryne increase and fertilizer (b) soil with ametryne increase (c) and soil addition of biofertilizer (d) 
It can be seen that the time of 31 day incubation period was sufficient to accumulate the $\mathrm{CO}_{2}$ from the consumption of organic matter during the metabolic activity of the microorganisms.

In systems with soil and adding ametryne (c) and control soil (a) the $\mathrm{CO}_{2}$ accumulation of settling time was lower compared to systems with biofertilizers increments. However, in systems with added ametryne and biofertilizer (S2) and soil biofertilizer (S4) the amount of $\mathrm{CO}_{2}$ accumulated was greater, because the biofertilizer has easily absorbed organic substrates for microbial metabolism.

Before and after the test respirometry Bartha \& Pramer the quantification of ametryne the soil matrix was performed. In the system with soil and ametryne was $41.03 \mathrm{mg} / \mathrm{kg}$ and the system with soil contaminated with ametryne and addition of biofertilizer was $34.74 \mathrm{mg} / \mathrm{kg}$. Thus, after 31 days of incubation of the soil, the herbicide has suffered biodegradation. The application of biofertilizers, enhanced the biodegradation of ametryne. Therefore, the addition of biofertilizer helped ametryne degradation in the soil, decreasing its persistence in the environment, favouring the aquatic and terrestrial ecosystem, ametryne since the molecule is very soluble in water.

\section{Discussion}

In the system with control soil (S1), the $\mathrm{CO}_{2}$ accumulation was lower compared to other systems, resulting in $48.981 \mathrm{mg}$, since it had low amount of carbon source available to the indigenous microbiota. It is known that the presence of persistent compounds in the environment may cause changes in the amount of nutrients available to the terrestrial microorganisms. This can worsen when organic matter is scarce and the nutritional carbon source is unavailable will microbial metabolism (Saha, 2012).

However, the control soil sample (S1) presented ametryne application history for the control of weeds in sugar cane crop, and during the test there was no addition of the herbicide. Thus, the molecule of ametryne is persistent in the environment and slow degradation (Lovecka et al., 2015), and may remain in the soil for many years (Shegunova et al., 2007).

By adding ametryne the soil (S3), the $\mathrm{CO}_{2}$ accumulation was higher in the control soil (S1). This is due to the soil with application ametryne history, and this probably has a specific microorganisms able to consume the molecule ametryne. Thus the herbicide served as carbon source for the local microflora (Zabaloy et al., 2008).

Probably there was a recovery of the indigenous microbial population in response to increasing the supply of nutrients arising from bacterial decomposition, resulting in the development of species resistant to the herbicide treatments (Gómez et al., 2014; Moreno et al., 2007).

It can be seen that when added to the soil biofertilizer with the addition of ametryne (S2), the $\mathrm{CO}_{2}$ concentration increased, totalling $68.157 \mathrm{mg}$ after 31 days of incubation, by passing the system with addition of soil and biofertilizer (S4) with $67.149 \mathrm{mg}$, in a total of $39.149 \%$ increase compared to control soil. This is due to the biostimulation and bioaugmentation produced by chemical and biological composition of biofertilizer (Pešaković et al., 2013). 
The biodegradation of ametryne can be assessed by soil microbial respiration, as the quantification of $\mathrm{CO}_{2}$ production. Thus, can to determine the optimal application rate of an herbicide. And evaluated application rates and nutrient concentration (Fiúza \& Vila, 2004; Miles \& Doucette, 2001; Montagnolli et al., 2009; Wu et al., 2004).

Adding biofertilizer, the amount of ametryne present in the soil decreased significantly, from $41.03 \mathrm{mg} / \mathrm{kg}$ in soil with ametryne to $34.74 \mathrm{mg} / \mathrm{kg}$ in soil with ametryne and biofertilizer. Thus, the organic substrate reduced the toxic effect of ametryne to the biological properties of the soil (Gomez et al., 2014).

The system S2 with soil and fertilizer ametryne, it can be seen that with the nutritional composition rich biofertilizer has meant that the enzymatic activity of the indigenous microflora to be stimulated and passed to metabolize possible degrading the soil, resulting in increased bacteria and fungi (Gomez et al., 2014), checked in increased generation of $\mathrm{CO}_{2}$.

Therefore, the introduction of alien species of microbes in conjunction with indigenous species to the contaminated soil, causes the environmental impacts caused by the presence of ametryne is reduced (Adesemoye \& Kloepper, 2009).

Thus, biofertilizer as organic compounds are rich in nutrients and microorganisms, are promising to be used integrated with other agricultural products, in order to alleviate environmental problems, since they have low financial cost (Pešaković et al., 2013; Hole et al., 2005).

\section{Conclusion}

The application of ametryne on the soil impaired microbiota metabolic activity, resulting in a low accumulation of $\mathrm{CO}_{2}$ throughout the incubation period. The addition of biofertilizer to the soil contaminated with ametryne favoured the accumulation of $\mathrm{CO}_{2}$, increasing microbial activity.

During the incubation period, the addition of biofertilizer assisted in biodegradation ametryne metabolizing molecule in the soil. Therefore, the addition of biofertilizer in soil with ametryne of application history, was essential to mitigate the degrading effect by caused the application of herbicides in the environment.

It is suggested the application of biofertilizer along with ametryne in soil contaminated by ametryne, in order to soften the aggressive and negative effect, due to the presence of molecule, promoting of the quality to terrestrial ecosystem.

\section{Acknowledgment}

Coordination Personnel Improvement Higher Education - CAPES- CnPQ.

\section{Conflicts of interest}

There are no conflicts of interest in this research. 


\section{References}

Adesemoye, A. O., Torbert, H. A., \& Kloepper, J. W. (2010). Increased plant uptake of nitrogen from 15N-depleted fertilizer using plant growth-promoting rhizobacteria. Applied Soil, 46(1), 54-58. https://doi.org/10.1016/j.apsoil.2010.06.010

Alfa, M. I., Adil, D. B., Igboro, S. B., Oranusi, U. S., Dahunsi, S. O., \& Akali, D. M. (2014). Assessment of biofertilizer quality and health implications of anaerobic digestion effluent of cow dung and chicken droppings. Renewable Energy, 63(1), 681-686. https://doi.org/10.106/j.renene.2013.09.049

Analytical methods for pesticide residues in foodstuffs. (2006). Ministery Public Health, Welfare and Sport, The Netherlands.

Andrade, M. M. M., Stamford, N. P., Santos, C. E. R. S., Freitas, A. D. S., Sousa, C. A., \& Junior, M. A. L. (2013). Effects of biofertilizer with diazotrophic bacteria and mycorrhizal fungi in soil attribute, cowpea nodulation yield and nutrient uptake in field conditions. Scientia Horticulturae, 162(23), 374-379. https://doi.org/10.106/j.scienta.2013.08.019

Banderi, A., Sheikh, M. M., Shomeli, M., \& Gol, A. S. D. (2012). Water Quality Assessment of Amir Kabir Sugarcane Agro-industry with Respect to Agricultural and Drinking Views. Journal of Environment and Ecology, 3(1). https://doi.org/10.5296/jee.v3i1.2353

Bartha, R., \& Pramer, D. (1965). Features of flask and method for measuring the persistence and biological effects of pesticides in soil. Soil Science, 100(1), 68-70.

CETESB. Environmental Sanitation and Technology Company (1990). Soils - residuals biodegradation determination - Bartha respirometric method. Technical Standard L6.350, São Paulo, Brazil.

CETESB. Environmental Sanitation and Technology Company. (1984). Soil-collection and sample preparation procedures. Technical Standard L6. 245, São Paulo, Brazil.

D’andrea, P. A. (2002). Processo de compostagem líquida contínua- CLC e Biofertilizante. Microbiol Indústria e Comércio LTDA. (BR/SP). NN 2099 Registro PI0207342-0 A2

Duarte, C. I., Andrade, D. C., Melo, R. P., Nagatomi, H. R., \& Mori, M. N. (2009). Decontamination of Ametryne HDPE packaging using electron beam accelerator. Radiation Physics and Chemistry, 78(7-8), 725-728. https://doi.org/10.1016/j.radphyschem.2009.03.067

Farré, M., Fernandez, J., Paez, M., Granada, L., Barba, L., Gutierrez, H.M., Pulgarin, C., \& Barceló, D. (2002). Analysis and toxicity of methomyl and ametryn after biodegradation. $\begin{array}{llll}\text { Analytical and Bioanalytical } \quad \text { Chemistry, } & \text { 373(8), }\end{array}$ https://doi.org/10.1007/s00216-002-1413-9

Fiúza, A. M. A., \& Vila, M. C. C. (2004). An insight into soil bioremediation through respirometry. Environment International, 31(2), 179-183. https://doi.org/10.1016/j.envint.2004.09.013.C 
Guidance document on pesticide residue analytical methods (2010). European Commission. SANCO/825/00.

Gómez, I., Rodríguez-Morgado, B., Parrado, J., García, C., Hernández, T., \& Tejada, M. (2014). Behavior of oxyfluorfen in soils amended with different sources of organic matter. Effects on soil biology. Journal of Hazardous Materials, 273(1), 207-2014. https://doi.org/10.1016/j.hazmat.2014.03.051

Hole, D. G., Perkins, A. J., Wilson, J. D., Alexander, I. A., Grice, P., \& Evans, A. D. (2005). Does organic farming benefit biodiversity? Biological Conservation, 122(1), 113-130. https://doi.org/10.1016/j.j.biocon.2004.07.018

Jilani, G., Akram, A., Ali, R. M., Hafeez, F. Y., Shamsi, I. H., Chaudhry, A. N., \& Chaudhry, A. G. (2007). Enhancing crop growth, nutrients availability, economics and beneficial rhizosphere microflora through organic and biofertilizers. Annals of Microbiology, 57(2), 177-183. https://doi.org/101007/BF03175204

Kasozi, G. N., Nkedi-Kizza, P., Li, Y., Zimmerman, A. R. (2012). Sorption of atrazine and ametryn by carbonatic and non-carbonatic soils of varied origin. Environmental Pollution, 169, 12-19. https://doi.org/10.1016/j.envpol.2012.05.002

Lima, D., Viana, P., André, S., Chelinho, S., Costa, C., Ribeiro, R., Sousa, J. P. Fialero, A. M., \& Viegas, C. A. (2009). Evaluating a bioremediation tool for atrazine contaminated soils in open soil microcosms: The effectiveness of bioaugmentation and bioestimulation approaches. Chemosphere, 74(2),

187-192. https://doi.org/10.1016/j.chemosphere.2008.09.083

Lovecka, P., Pacovska, I., Stursa, P., Vrchotova, B., Kochankova, L., \& Demnerova, K. Organochlorinated isolated from contaminated soil. New Biotechnology, 32(1), 26-31. https://doi.org/10.1016/j.nbt.2014.07.003

Miles, R. A., \& Doucette, W. J. (2001). Assessing the aerobic biodegradability of 14 hydrocarbons in two soils using a simple microcosm/ respiration method. Chemosphere, 45(6-7), 1085-1090. https://doi.org/10.1016/S0045-6535(01)00012-1

Mohammad, A., Amel, A., \& Alizadeh, N. (2009). Headspace solid-phase microextraction using a dodecylsulfate-doped polypynole film coupled to ion mobility spectrometry for the simultaneous determination of atrazine and ametryne in soil and water samples. Talanta, 78 (3), 1107-1114. https://doi.org/10.1016/j.talanta.2009.01.025

Montagnolli, R. N., Lopes, R. M. P., \& Bidoia, E. D. (2009). Applied models to biodegradation kinetics of lubricant and vegetable oils in wastewater. International $\begin{array}{llll}\text { Biodeterioration } \quad \& \quad \text { Biodegradation, } & \text { 63(3), }\end{array}$ https://doi.org/10.1016/j.ibiod.2008.10.005

Moreno, J. L., Aliaga, A., Navarro, S., Hernández, T., \& García, C. (2007). Effects of atrazine on microbial activity in semiarid soil. Applied Soil Ecology, 35(1), 120-137. https://doi.org/10.1016/j.apsoil.2006.05.002 
Navaratna, D., Elliman, J., Copper, A., Shu, L., Baskaran, K. \& Jegatheesan, V. (2012). Impact of herbicide Ametryn on microbial communities in mixed liquor of a membrane $\begin{array}{lllll}\text { bioreactor } \quad \text { (MBR). } & \text { Bioresource }\end{array}$ https://doi.org/10.106/j.biortech.2011.12.0.18

Pešaković, M., Karaklajić-Stajić, Z., Milenković, S., \& Mitrović, O. (2013). Biofertilizer affecting yield realted chracteristcs of strawberry (Fragaria $\times$ ananassa Duch.) and soil $\begin{array}{llll}\text { microorganisms. } & \text { Scientia } \quad \text { Horticulture, } & \text { 238-243. }\end{array}$ https://doi.org/10.106/j.scienta.2012.11.016

Régo, A. P. J., Reganhan-Coneglian, C. M., Montagnolli, R. N., \& Bidoia, E. D. (2014). CO2 production of soil microbiota in the presence of ametryne and biofertilizer. Water Air Soil Pollution, 225, 1-6. https://doi.org/10.1007/s11270-014-2222-4

Saha, S., Dutta, D., Karmakar, R., \& Ray, D. P. (2012). Structure -toxicity relationship of chloroacetamilide herbicides: Relative impact on soil microoganisms. Environmental Toxicology and Pharmacology, 34(2), 307-314. https://doi.org/10.106/j/etap.2012.04.014

Sandoval-Carrasco, C. A., Chacón-Ahuatzi, D., Mayer-Galíndez, J., Ordaz-Ruiz, N., Ramírez-Juárez, C., \& Jeronímo-Martínez, F. (2013). Biodegradation of a mixture of the herbicides ametryne, and 2, 4-dichlorophenoxyacetic acid (2,4-D) in a compartmentalized $\begin{array}{lllll}\text { biofilm } \quad \text { reactor. } & \text { Bioressource } & \text { Technology, } & \text { 145, }\end{array}$ https://doi.org/10.106/j.biortech.2013.02.068

Shegunova, P., Klánová, J., \& Holoubek, I. (2007). Residues of organochlorinated pesticides in soils from the Czech Republic. Environmental Pollution, 145(1), 33-36. https://doi.org/10.1016/j.env.pol.2006.03.057

Schmidt, S. K., Simkins, S., \& Alexander, M. (1985). Models for the kinetics of biodegradation of organic compounds not supporting growth. Applied and Environmental Microbiology, 50(2), 323-331.

Vessey, J. K. Plant growth promoting rhizobacteria as biofertilizers. (2003). Plant and Soil, 255(2), 571-586.

Zabaloy, M. C., Garland, J. L., \& Gómez, M. A. (2008). An integrated approach to evaluate the impacts of the herbicides glyphosate, 2,4-D and metsulfuron-methyl on soil microbial communities in the Pampas region, Argentina. Applied Soil Ecology, 40(1), 1-12. https://doi.org/10.106/j.apsoil.2008.02.004

Wu, S. C., Cao, Z. H., Li, Z. G., Chegung, K. C., \& Wong, M. H. (2005). Effects of biofertilizer containing $\mathrm{N}$-fixer, $\mathrm{P}$ and $\mathrm{K}$ solubilizers and AM fungi on maize growth: a greenhouse trial. Geoderma, 125(1-2), 155-156. https://doi.org/10.1016/j.geoderma.2004.07.003

Wu, Y., Chiang, C., \& Lu, C. (2004). Respirometric evaluation by graphical analysis for microbial systems. Environment Monitoring and Assessment, 92(1-3), 137-152. http://dx.doi.10.1023/B:EMAS.0000014499.01371.1c 


\section{Copyrights}

Copyright for this article is retained by the author(s), with first publication rights granted to the journal.

This is an open-access article distributed under the terms and conditions of the Creative Commons Attribution license (http://creativecommons.org/licenses/by/4.0/) 